інтересів, особливостей темпераменту і характеру, вміти ставити цілі і мотивувати підлеглих до виконання професійних обов'язків.

У результаті здійсненого аналізу професійних обов'язків, виробничих функцій, типових задач професійної діяльності фахівців агрономічного профілю, потенціалу фаху щодо працевлаштування і застосування на практиці набутих професійних знань, умінь і навичок, було виявлено специфіку їхньої професійної діяльності та виокремлено в ній психологічний складник.

\title{
Література
}

1. Андрійчук В. Г. Економіка аграрних підприємств : [підручник] В. Г. Андрійчук. - К. : КНЕУ, 2002. - 624 с. 2. Введення до спеціальності : [навч. посіб.] / за ред. І. Д. Примака, О. І. Примак. - К. : Центр учбової літератури, 2009. 392 с. 3. Грецов А. 100 популярных профессий. Психология успешной карьеры для старшеклассников и студентов / А. Грецов, Т. Бедарева. - СПб. : Питер, 2008. 272 с. 4. Економічна теорія: [посібник] / за заг. ред. Є. М. Воробйова. - ХарківКиїв : Корвін, 2003. - 704 с.

\section{Олександра Потапова}

\section{ДО ПРОБЛЕМИ ФОРМУВАННЯ КРИТИЧНОГО МИСЛЕННЯ У СТУДЕНТІВ ТЕХНІЧНИХ ВНЗ ПІД ЧАС ВИВЧЕННЯ МАТЕМАТИЧНИХ ДИСЦИПЛІН}

Потапова О. М. До проблеми формування критичного мислення у студентів технічних ВНЗ під час вивчення математичних дисциплін.

У статті досліджується проблема розвитку критичного мислення студентів вищих навчальних закладів в науковій i методичній літературі. На основі зіставлення, порівняння, узагальнення наукової інформації уточнюється сутність поняття «критичне мислення» та доводиться необхідність його формування у студентів ВНЗ як складника майбутньої фахової компетентності.

Ключові слова: математичні дисципліни, критичне мислення, технічний вищий навчальний заклад, професійна компетентність.

Потапова О.Н. К К проблеме формирования критического мышления у студентов технических вузов при изучении математических дисциплин.

В статье исследуется проблема развития критического мышления студентов высших учебных заведений в научной и методической литературе. На основе сопоставления, сравнения, обобщения научной информации уточняется сущность понятия «критическое мышление» и обосновывается необходимость его формирования у студентов высших учебных заведений как составляющей будущей профессиональной компетентности.

Ключевые слова: математические дисциплины, критическое мышление, техническое высшее учебное заведение, профессиональная компетентность.

Potapova A. N. On the problem in formation of critical thinking by the students of technical higher education institution in the studying of mathematical disciplines.

The problem of developing critical thinking by students of technical higher education institution is researched in this article, with the help of scientific and technical literature. The essence of the concept of «critical thinking» is determined on the basis of formation, composition and generalization of scientific information and is proved the 
necessity of its formation with students of technical higher education institution as part of their future professional competence.

Key words: mathematical discipline, critical thinking, technical higher education institution, professional competence.

Соціальні зміни й новітні досягнення сучасної науки і практики висувають високі вимоги до мисленнєвих здібностей спеціаліста. Наприкінці навчання випускники технічного університету, як майбутні інженери, повинні набути вміння обгрунтовувати, розробляти й досліджувати математичні моделі технічних об'єктів, a підгрунтям вище зазначених професійних умінь $\epsilon$ математичне мислення студентів, складником якого $\epsilon$ критичне мислення. Актуальність проблеми формування критичного мислення особистості зумовлена притаманною нашому часу динамікою технологічного та соціального прогресу, що вимагає умінь швидкого пристосування до умов професійної діяльності; змінювати і вдосконалювати іiі на основі самостійного набуття знань; знаходження шляхів розв'язання професійних і соціальних завдань у нестандартних ситуаціях; пошуку внутрішнього потенціалу задля гармонійної адаптації в полікультурному світі. Тому формування й розвиток критичного мислення в освітньому процесі технічних ВНЗ $€$ одним із провідних завдань системи вищої професійної освіти.

Проблемі формування критичного мислення присвячено праці багатьох науковців (В. Джемса, Дж. Дьюї, Д. Клустера, Р. Стернберг, Д. Стіл, Ч. Темпл, Д. Халперн та ін.), зокрема, принципи й закономірності функціонування критичного мислення в контексті загальних розумових здібностей досліджували В. Біблер, М. Вертгеймер, С. Заір-Бек, І. Ільясов, 3. Калмикова, О. Матюшкін, М. Махмутов, С. Рубінштейн та ін. Значення критичності у структурі особистості висвітлювали П. Блонський, Б. Теплов та ін.

Значний внесок у теорію та практику розвитку критичного мислення української студентської молоді належить вітчизняним науковцям (Л. КиєнкоРоманюк, О. Колесовій, В. Майбороді, О. Марченко, Т. Олійнику, С. Почтовюк, С. Терно, О. Тягло, Т. Хачумян).

Mema cmammi- дослідити проблему формування критичного мислення в науковій і методичній літературі та визначити шляхи його розвитку у студентів технічних спеціальностей ВНЗ під час вивчення математичних дисциплін.

Досліджуючи вплив мислення на успіх засвоєння математичних знань, науковці зазначають, що результативність у навчанні визначається рівнем розвитку таких якостей, як: просторова уява, вміння відрізняти суттєве від несуттєвого, вміння абстрагувати й абстрактно мислити, вміння від окремої ситуації перейти до математичного формулювання питання, навички дедуктивного мислення, аналіз, синтез, уміння критикувати і ставити нові питання. Успішність математичної діяльності також залежить від таких якостей, як: активного позитивного ставлення до неї; низки характерологічних рис (працьовитість, організованість, самостійність, цілеспрямованість, наполегливість, стійкі інтелектуальні здібності; певний фонд знань, навички й уміння 3 відповідної галузі; наявність під час здійснення діяльності сприятливого задля іiі виконання психологічного стану, наприклад, зацікавленості, зосередженості, гарного «психічного» самопочуття. Водночас В. Крутецький [5, с. 85] наголошує, що якщо людина не має мінімуму знань, навичок та умінь із математики, то не може бути здатною навіть до найпростішої математичної діяльності, хоча володіє математичними здібностями. 
Отже, математика є однією з основних дисциплін, навчання якої дозволяє формувати логічне, образне, просторове, творче, а також критичне мислення учнів.

Ідея розвитку критичного мислення належить відомим американським психологам XX ст. В. Джемсу та Дж. Дьюї. Пізніше, теорія формування критичного мислення учнів розробляється й поглиблюється в дослідженнях західних науковців Р. Стернберг, Д. Стіл, Ч. Темпл, Д. Халперн, Д. Клустер та ін..

Нині в наукових джерелах можна знайти різні визначення критичного мислення. Так, Джуді А. Браус та Д. Вуд визначають критичне мислення як розумне рефлексивне мислення, сфокусоване на розв'язанні того, у що вірити і що робити. Д. Халперн у своїй роботі «Психологія критичного мислення» відзначає, що «критичне мислення означає не негативність суджень і критику, а розумний розгляд різноманітних рішень проблеми, для того щоб виносити обгрунтовані судження, тобто «критичне» може розумітися як «аналітичне». Коли ми мислимо, - пояснює Д. Халперн, - оцінюємо результати своїх розумових процесів - наскільки правильно прийняте рішення або наскільки вдало розв'язали завдання. Отже, критичне мислення охоплює оцінку мисленнєвого процесу - ходу міркувань, які привели до наших висновків, або тих фактів, які ми враховували під час прийняття рішення» [9, с. 70]. Критичне мислення іноді називають спрямованим, оскільки воно має вектор на отримання бажаного результату.

Д. Клустер визначає критичне мислення як сукупність п'яти характеристик. По-перше, це мислення самостійне, що має індивідуальний характер. По-друге, наявність у студентів певних знань, інформації, що $є$ відправним i аж ніяк не кінцевим пунктом критичного мислення. Знання $\epsilon$ мотивом, без чого людина не може мислити критично. По-третє, критичне мислення проблемне й оціночне; засноване на постановці питань і з'ясуванні проблем. На думку Дж. Дьюї, звернення студентів до конкретної проблеми стимулює їх природну допитливість та спонукає до критичного мислення. По-четверте, критичне мислення прагне переконливої аргументації, власного розв'язання проблеми, підкріпленого логічними i раціональними доказами. По-п'яте, критичне мислення є мисленням соціальним.

На необхідність формування навичок критичного мислення в сучасної молоді ще на початку дев'яностих років минулого століття звернув увагу український дослідник В. Майборода. У своїй праці «Розвиток критичного мислення спеціалістів при вивченні питань історії професійної освіти» розглядав технології, що допомагають педагогу зробити навчально-виховний процес більш цікавим, різноманітним, ефективним, демократичним. Т. Олійник пропонує «Курс «критичне мислення» для студентів та викладачів університетів». Головною характеристикою курсу є «групове навчання/викладання через дискусійні та письмові форми роботи, що спрямоване на вироблення незалежної позиції розв'язання проблем розвитку сучасного суспільства...».

На думку відомого українського дослідника О. Тягла, критичне мислення забезпечує систематичне вдосконалення процесу й результатів розумової діяльності на основі іiі критичного аналізу, розуміння й оцінки. У своїй книзі «Критичне мислення» [8, с. 12] автор відзначає, що коли розум людини спрямовується на дослідження міркувань задля виявлення й усунення можливих помилок і похибокопонента чи своїх - можна говорити про критику або критичне мислення загалом. Отже, критичне мислення може бути спрямованим як на логічні помилки, так і на помилки змістовні, наприклад, пов'язані 3 хибною інформацією. У науковому доробку вивчає конкретний випадок критичного мислення у вузькому розумінні, 
коли воно грунтується на елементарній науці логіки $\mathrm{i}$ може розумітися як специфічний різновид рефлексії, що спирається на знання елементарної логіки й відповідних конкретних наук.

У дослідженнях О. Марченко критичне мислення як продукт педагогічної діяльності передбачає обгрунтування тими, хто навчається, власних думок, тверджень, дій, спроможність оцінити раціональність, подолання упередженості в діяльності і взаєминах з іншими, самостійного орієнтування в довкіллі, критичного ставлення до сучасного процесу інтеграції, здатності розпізнавати правильні й неправильні, випадкові узагальнення, що допомагає студентам бачити невизначеність і помилковість пропонованих суджень.

У своїй праці С. Терно [7, с. 6] стверджує, що критичне мислення - це наукове мислення, сутність якого полягає в ухваленні ретельно обміркованих та зважених рішень стосовно довіри до будь-якого твердження: чи мусимо ми сприйняти, чи відкинути або відкласти, а також ступінь упевненості, з яким ми це робимо. Учений наголошує, що критичне мислення означає не негативність суджень або критику, а зважений розгляд різноманітних підходів до проблеми, задля прийняття обгрунтованих суджень та рішень. Критична особистість має здібність і прагнення оцінювати різні твердження й робити об'єктивні судження на основі добре обгрунтованих переконань. Мета критичного мислення полягає у встановленні об'єктивної істини.

Л. Києнко-Романюк переконує, що «критичне мислення - це специфічний мисленнєвий процес, який здійснюється одночасно 3 логічним, аналітичним, креативним та іншими видами і вирізняється 3-поміж них тим, що на виході формує не лише вміння свідомого аналізу, синтезу, різнобічного бачення проблеми тощо, а й позиції, духовної наповненості особистості. Від технології розвитку критичного мислення залежить, якою буде поведінка особистості: відповідальною, толерантною, моральною чи нігілістичною, егоцентричною, потенційно руйнівною для суспільної стабільності» [3, с. 170].

На думку А. Авершин і Т. Яковенко [1, с. 2], критичне мислення пов'язане 3 логікою й аргументацією, раціональністю й усвідомленістю. Його роль - у контролі над виконанням інтелектуальної діяльності з метою підвищення ефективності. На противагу інтуїтивному мисленню, яке передбачає виявлення здатності побачити правильну відповідь без можливості обгрунтувати рішення і довести його правильність, критичне мислення працює за рахунок конкретних процедур i стратегій, які й підвищують вірогідність подолання проблемних ситуацій. Критичне мислення за допомогою оцінки, селекції й аргументації процесу роботи 3 проблемною ситуацією забезпечує обгрунтований вибір подальшого прийняття рішення.

Під критичним мисленням О. Колесова [4, с. 8] розуміє такий вид мислення, який спрямовано на аналіз інформації 3 позиції логіки й особистіснопсихологічного підходу 3 тим, щоб отримати за рахунок розв'язання бажані результати та застосовувати їх як до стандартних, так і до нестандартних ситуацій, питань і проблем.

Прийнятним для нашого дослідження є означення Т. Хачумян: «Критичне мислення - це особливий різновид мисленнєвої діяльності, характерними ознаками якого $\epsilon$ : вироблення стратегій прийняття правильних рішень у розв'язанні будь-яких завдань на основі здобуття, аналізу, опрацювання інформації; здійснення рефлексивних дій (аналітичних, перевірочних, 
контрольних, оцінних), виконуваних стосовно будь-якого об'єкта чи явища, зокрема власного процесу мислення; виважений аналіз різних думок і поглядів, виявлення власної позиції, об'єктивне оцінювання процесу і результатів як своєї, так і сторонньої діяльності» [10, с. 175].

Отже, наявні різні підходи науковців щодо визначення критичного мислення, проте, всі близькі за змістом. Критичне мислення - це мислення оцінне, рефлексивне; відкрите мислення, яке не приймає догм та розвивається шляхом накладення нової інформації на особистий життєвий досвід. У цьому є його відмінність від творчого мислення, яке не передбачає оцінювання, а припускає продукування нових ідей, що часто виходять за межі життєвого досвіду, зовнішніх норм та правил. Однак провести чітку межу між критичним і творчим мисленням складно. Розпочавши аналізувати проблему, ми висуваємо гіпотези, відшукуємо альтернативні способи розв'язання. Можна сказати, що критичне мислення - це відправна точка розвитку творчого мислення, більш того, і критичне, і творче мислення розвиваються в синтезі, взаємозумовлено.

Д. Халперн вважає [9, с. 70], що для того щоб студент зміг скористатися своїми можливостями критичного мислителя, необхідно, щоб він розвив у собі низку важливих якостей:

1. Готовність до планування. Думки часто виникають хаотично. Важливо упорядкувати їх, розв'язати, з'ясувати порядок викладення. Упорядкованість думок - ознака впевненості.

2. Гнучкість. Якщо студент не готовий сприймати ідеї інших, відповідно, не зможе стати генератором ідей. Гнучкість дозволяє регулювати етап винесення судження, поки він (студент) не володітиме різноманітною інформацією.

3. Наполегливість. Часто, стикаючись зі складним завданням, ми намагаємося відкласти розв'язання. Розвиваючи наполегливість у напрузі розуму, студент обов'язково досягне значних результатів навчання.

4. Готовність виправляти свої помилки. Людина, яка мислить критично, не наполягатиме на хибних рішеннях, а зробить вірогідні висновки, врахувавши помилку задля продовження навчання.

5. Усвідомлення. Д. Халперн уважає, що ця якість є важливою і припускає вміння самоспостереження у процесі розумової діяльності, відстежувати хід міркувань.

6. Пошук компромісних рішень. Важливо, щоб прийняті рішення могли сприйняти інші люди, інакше ці рішення залишаться на рівні висловлень.

До основних рис критичного мислення С. Терно [7, с. 5] відносить такі вміння: 1) робити логічні умовиводи; 2) приймати обгрунтовані рішення; 3) надавати оцінку позитивних та негативних рис як отриманої інформації, так і самого розумового процесу; 4) спрямованість на результат.

У дослідженнях С. Почтовюк [6, с. 139] метою розвитку критичного мислення у студентів є формування в єдності і взаємозв'язках таких його якостей, як:

1) логічність: уміння будувати логічні твердження; мислити індуктивно й дедуктивно; оцінювання причинно-наслідкових зв'язків досліджуваних явищ та відповідності між етапами розв'язання задачі, операціями мислення; узгодження й перевірка результатів на основі певних критеріїв;

2) гнучкість: властивість мислення, яка забезпечує його операційність, уміння переносити знання та навички в нові ситуації на основі здійснення проблемнопошукової діяльності; готовності до використання нової комп'ютерної техніки та 
нового програмного забезпечення; готовності до подальшої самоосвіти; аналізу й порівнянні; оцінюванні оригінальності розв'язання задачі; готовності виправляти помилки; пошуку компромісних рішень;

3) цілісність: оцінювання необхідності та доцільності того або того інтелектуального процесу або операції в діяльності; цілісність мислення пов'язана 3 опануванням учнями сукупністю знань, умінь i навичок, необхідних для повсякденного життя й майбутньої професійної діяльності; виявляється в баченні об'єктів і явищ загалом, взаємозв'язках, у здатності охопити весь процес розв'язування задачі, не втрачаючи вхідних даних; в оцінюванні загальної структурності процесу розв'язування задачі, а зрештою, і свого процесу мислення;

4) широта: виражається в пізнавальній діяльності людини, широкому світогляді, різносторонній допитливості. Широта як якість мислення грунтується на всебічних і глибинних знаннях; виявляється в застосуванні до розв'язання задач необхідних засобів і знань, не даних безпосередньо в умовах задачі, а взятих 3 інших галузей знань, наук тощо.

Наведені якості критичного мислення необхідно розглядати в єдності i взаємозв'язках, кожна з яких взаємодоповнюється.

Ураховуючи специфіку професійної діяльності, О. Колесова [4, с. 8] виокремлює такі компоненти критичного мислення:

- когнітивний: передбачає постійне поповнення й оновлення знань як найважливішого аспекту діяльності спеціаліста, оскільки обсяг інформації, необхідної для ефективної професійної діяльності, стрімко зростає;

- мотиваційний: передбачає, що для будь-якої успішної діяльності необхідною вихідною умовою $\epsilon$ наявність відповідної мотивації. «Стартовим механізмом критичного мислення, - як зазначає В. Ружжейро, - $є$ схильність бути допитливим, дивуватися, шукати відповіді на запитання». Якщо людина запитує себе: «Як це відбулося? Чому це так, а не інакше? Що тут не так?»- тим самим вона виходить на шлях до правильного визначення проблеми;

- рефлексивний: передбачає взаємопов'язаність критичності мислення та рефлексії. Дж. Дьюї використовує поняття «рефлексивне мислення», що визначається як дія, яка є умовою того, що наявні факти викликають інші факти або істини так, щоб сформувати впевненість в останніх на основі або за гарантії перших. Рефлексивне мислення поєднує принципи індукції й дедукції: індуктивне відкриття є процесом утворення ідеї; дедуктивне доведення є процесом розвитку, використання та перевірки фактичних даних;

- діяльнісний: передбачає залежність функціонування певної галузі від діяльності фахівців, і рішення одного фахівця стосується інтересів багатьох учасників.

У науковому доробку Т. Хачумян [10, с. 173] наводить структуру критичного мислення в єдності кількох взаємопов'язаних складників (компонентів):

1) мотиваційний: ставлення особистості до процесу пізнання, до завдань, які доводиться виконувати; забезпечує розуміння необхідності тих чи тих знань, умінь та навичок, свідому зацікавленість щодо їх набуття; забезпечує потребу та готовність використовувати набуті знання, уміння та навички в подальшій діяльності задля осмислення, усвідомлення, аналізу явищ, об'єктів, на які спрямовано процес мислення;

2) змістовий: наявність сукупності знань із предметної галузі, у якій здійснюється діяльність критичного мислення; знання про способи пошуку, 
опрацювання, перетворення інформації, методи пошукової (дослідницької) діяльності, прийоми самоконтролю та самокорекції діяльності;

3) інтелектуально-процесуальний: формування у студентів сукупності вмінь і навичок, завдяки яким реалізуються дії, характерні для критичного мислення;

3) емоційно-вольовий: емоційне ставлення до виконуваного завдання, наполегливість, воля, цілеспрямованість, певна заповзятість у розв'язанні поставленої проблеми, готовність докладати зусилля з подолання труднощів.

Дослідниця наголошує, що для розвитку критичного мислення у студентів необхідно в навчальному процесі використовувати такі методи, форми, засоби навчання, створювати умови, які б забезпечували формування всіх компонентів. Проте, основним у структурі критичного мислення окреслює інтелектуальнопроцесуальний компонент - сукупність специфічних умінь, навичок та прийомів, що забезпечують виконання дій, характерних для критичного мислення. У складі цього компоненту визначено найістотніші вміння, які об'єднано у три групи: інформаційно-гностичні, контрольно-рефлексивні, дослідницькі. В основу групи інформаційно-гностичних умінь покладено вміння здобувати й опрацьовувати інформацію, використовувати іï задля розв'язання поставлених завдань, набуття нових знань; в основу групи контрольно-рефлексивних умінь покладено вміння контролювати й оцінювати процес i результати діяльності, як власної, так i сторонньої; в основу групи дослідницьких умінь - уміння використовувати науково-дослідницькі методи задля розв'язання поставлених завдань.

А. Сферова висуває принципи, на основі яких виникає, функціонує i розвивається процес формування критичного мислення студентів технічних ВНЗ: цілісності, системності, динамічності, розвитку, відкритості, суб'єктності. Вона також формулює педагогічні умови формування критичного мислення студентів:

- застосування змістовного потенціалу курсу;

- високий рівень сформованості критичного мислення у викладачів;

- застосування інформаційних технологій у процесі формування критичного мислення у студентів;

- психологічна установка на розвиток критичного мислення у студентів;

- застосування активних методів навчання [2, с. 72].

Усі вищезазначені якості і вміння, характерні для критичного мислення, важливі для успішного засвоєння математичних знань. А сформоване у студентів технічних спеціальностей ВНЗ критичне мислення є важливим чинником успішної майбутньої професійної діяльності.

С. Почтовюк [6, с. 138] також пропонує на заняттях 3 математичних та інформативних дисциплін виділяти час, коли студенти можуть дискутувати, ставити питання і відповідати на них (створювати умови для діалогу між викладачем i студентами, між суб'єктами навчання). При цьому питання, повинні бути спрямовані на переосмислення раніше вивченого, конкретизацію або практичне застосування теоретичних знань, потреби прогнозувати, знаходити взаємозв'язки між поняттями, явищами або об'єктами. Отже, необхідно зробити так, щоб студенти не сприймали все на віру, а могли самостійно або за допомогою викладача з'ясувати сутність, вміли побудувати стійкі причинно-наслідкові зв'язки певної проблеми.

Отже, для формування критичного мислення у процесі вивчення математичних дисциплін необхідно організувати роботу за такими напрямками:

- застосування системи задач, спрямованих на формування критичного мислення на практичних і лабораторних заняттях із математичних дисциплін; 
- виявлення зворотного зв'язку на лекційних заняттях;

- підготовка дослідницьких завдань, спрямованих на критичне осмислення результатів пошукової роботи;

- самостійне застосування студентами отриманих знань і умінь у новій нестандартній ситуації.

Отже, виникає необхідність в організації процесу навчання математичних дисциплін студентів технічних ВНЗ, за якого водночас із формуванням математичних знань, умінь і навичок відбувається цілеспрямоване формування критичного мислення студентів. Задля цього ставиться задача побудови моделі формування критичного мислення у студентів технічних ВНЗ під час вивчення математичних дисциплін, зокрема математичного аналізу, та створенні відповідного навчально-методичного комплексу, що задовольняє властивостям: комплекс реалізується під час аудиторної та самостійної роботи студентів; комплекс зорієнтований як на формування математичних знань, умінь і навичок, так і на формування критичного мислення студентів.

Із досліджень науковців можна зробити висновок, що розвиток критичного мислення $\epsilon$ складником професійного становлення особистості майбутнього фахівця, у процесі чого набуваються ознаки фахової компетентності.

Формування критичного мислення у студентів технічних ВНЗ у процесі навчання математичного аналізу сприятиме покращенню якості математичних знань, підвищенню рівня навчальної мотивації, пізнавальної активності, формуванню більш високого рівня самооцінки. У процесі навчання, спрямованого на формування критичного мислення, студенти набувають таких якостей, як: готовність до планування, гнучкість, наполегливість, усвідомлення, готовність виправляти помилки, пошук компромісних рішень, що $є$ важливими для майбутнього інженера.

\section{Література}

1. Авершин А. О. Формування критичного мислення у студентів інженернопедагогічних ВНЗ [Електронний ресурс] / А. О. Авершин, Т. В. Яковенко. - Режим доступу: http://at.zavantag.com/download/docs-100428/ 162-100428.doc.

2. Еферова А. Р. Педагогические условия формирования критического мышления студентов в образовательном процессе технического вуза : дис. ... канд. пед. наук: 13.00.01 / Еферова Аделя Рафиковна. - Астрахань : АГТУ, 2010. - 211 с. 3. КиєнкоРоманюк Л. А. Формування світогляду молоді через розвиток критичного мислення / Л. А. Києнко-Романюк // Теоретико-методичні проблеми виховання дітей та молоді : зб. наук. праць. - К. : Волинь, 2003. - Кн. І. - С. $168-171$. 4. Колесова О. П. Формування критичного мислення у майбутніх економістів засобами інтерактивних технологій навчання: автореф. дис. на здобуття наук. ступеню канд. пед. наук : 13.00.04 / О. П. Колесова; Класич. приват. ун-т. Запоріжжя, 2010. - 20 с. 5. Крутецкий В. А. Психология математических способностей школьников; под ред. Н. И. Чуприковой. - М. : Институт практической психологии; Воронеж : Изд-во НПО «МОДЭК», 1998. - 416 с. (Серия «Психологи отечества»). 6. Почтовюк С. I. Модель формування критичного мислення студентів технічних коледжів в процесі навчання інформатики / C. I. Почтовюк// Науковий часопис Національного педагогічного університету ім. М. П. Драгоманова. Серія 2. - Комп’ютерно-орієнтовані системи навчання : [зб. наук. праць] / М-во освіти і науки України, Нац. пед. ун-т ім. М. П. Драгоманова. К. : Вид-во НПУ ім. М. П. Драгоманова, 2011. - Вип. 11.- С. 135-141. 
7. Терно С. О. Критичне мислення - сучасний вимір суспільствознавчої освіти / С. О. Терно. - Запоріжжя : Просвіта, 2009. - 268 с. 8. Тягло О. В. Критичне мислення: [навч. посіб.] / О. В Тягло. - Х. : Основа, Вип. 1(61). - 2008 - 192 с. 9. Халперн Д. Психология критического мышления / Д. Халперн. - СПб. : Питер, 2000. - 512 с. 10. Хачумян Т. І. Поняття «критичне мислення» та його сутність в психолого-педагогічній науці / Т. І. Хачумян // Теоретичні питання культури, освіти та виховання : [3б. наук. пр.] - Вип. 24. -Ч. 2. - К. : Вид. центр КНЛУ, 2003. - С. 171-177.

УДК 738:37.011.3-051:005.336.5

Інна Талащ

\section{РОЗВИТОК ЗДАТНОСТІ ДО ПЕДАГОГІЧНОЇ ТВОРЧОСТІ МАЙБУТНІХ УЧИТЕЛІВ ПОЧАТКОВИХ КЛАСІВ}

Талаш І. О. Розвиток здатності до педагогічної творчості майбутніх учителів початкових класів.

У статті зроблено спробу проаналізувати етапи розвитку здатності майбутніх учителів до педагогічної творчості, з'ясувати чинники, що впливають на розвиток творчої особистості студентів педагогічних факультетів, виявити потенційні можливості інноваційних педагогічних технологій у процесі становлення особистості майбутнього професіонала.

Ключові слова: творчість, педагогічна творчість, дивергентне мислення, інноваційні педагогічні технології, кредитно-модульна система навчання.

Талаш И. А. Развитие способности к педагогическому творчеству будущих учителей начальных классов.

В статье сделана попытка проанализировать этапы развития способности будущих учителей к педагогическому творчеству, выяснить факторы, влияющие на развитие творческой личности студентов педагогических факультетов, определить потенциальные возможности инновационных педагогических технологий в процессе становления личности будущего профессионала.

Ключевые слова: творчество, педагогическое творчество, дивергентное мышление, инновационные педагогические технологии, кредитно-модульная система обучения.

Talash I. A. Development of ability to pedagogical creativity of future elementary school teachers.

The article attempts to analyze the stages of development of the ability of future teachers for pedagogical creativity, find out the factors affecting the development of the creative personality of students of pedagogical faculties, identify potential innovative pedagogical technologies in the making of a future professional.

Key words: creativity, pedagogical creativity, divergent thinking, innovative educational technology, credit-modular system of training.

Сучасна початкова школа вимагає творчого вчителя, який вміє гнучко адаптуватися до інновацій і реформ, що впроваджуються в навчально-виховний процес, організовувати взаємодію з учнями на засадах особистісно зорієнтованого навчання. Важливість розв'язання означеної проблеми підкреслюється у державних програмах. Одним із стратегічних завдань, окреслених у Державній національній програмі «Освіта» («Україна XXI століття)), є створення умов для формування освіченої, творчої 